\title{
STUDI KOMPARASI MODEL PEMBELAJARAN PROBLEM SOLVING SECARA ALGORITMIK DAN HEURISTIK DITINJAU DARI KEMAMPUAN BERPIKIR KRITIS TERHADAP PRESTASI BELAJAR SISWA KELAS XI MIPA PADA MATERI HIDROLISIS SMA NEGERI 4 SURAKARTA TAHUN PELAJARAN 2016/2017
}

\author{
Elda Frediana Rety Kartika, Bakti Mulyani* dan Elfi Susanti VH \\ Program Studi Pendidikan Kimia, FKIP, Universitas Sebelas Maret, Surakarta, Indonesia \\ *keperluan korespondensi, telp/fax: 08122761216, email: baktimulyani@gmail.com
}

\begin{abstract}
ABSTRAK
Penelitian ini bertujuan untuk mengetahui (1) pengaruh penggunaan model pembelajaran Problem Solving secara algoritmik dan heuristik terhadap prestasi belajar siswa pada materi hidrolisis garam (2) pengaruh kemampuan berpikir kritis terhadap prestasi belajar siswa pada materi hidrolisis garam (3) interaksi model pembelajaran Problem Solving secara algoritmik dan heuristik dengan kemampuan berpikir kritis terhadap prestasi belajar siswa pada materi hidrolisis garam. Subjek penelitian ini adalah siswa kelas XI MIPA 5 dan XI MIPA 7 SMA Negeri 4 Surakarta tahun pelajaran 2016/2017 yang diambil dengan teknik cluster random sampling. Analisis data prestasi aspek pengetahuan menggunakan analisis variansi (anava) dua jalan dengan faktor $2 \times 2$ dan frekuensi sel tak sama, sedangkan analisis data prestasi aspek sikap dan keterampilan menggunakan uji statistik non parametrik Kruskal Wallis $\mathrm{H}$. Hasil penelitian memperoleh kesimpulan sebagai berikut: (1) terdapat pengaruh model pembelajaran Problem Solving secara algoritmik dan heuristik terhadap prestasi belajar siswa aspek pengetahuan, tetapi tidak untuk aspek afektif dan ketrampilan (2) terdapat pengaruh kemampuan berpikir kritis terhadap prestasi belajar aspek kognitif dan ketrampilan, sedangkan pada aspek afektif tidak ada pengaruh kemampuan berpikir kritis terhadap prestasi belajar siswa pada materi hidrolisis garam (3) Tidak ada interaksi antara model pembelajaran Problem Solving secara algoritmik dan heuristik dengan kemampuan berpikir kritis terhadap prestasi belajar aspek pengetahuan, sikap, maupun ketrampilan pada materi hidrolisis garam.
\end{abstract}

Kata Kunci : Problem Solving, algoritmik, heuristik, kemampuan berpikir kritis, prestasi belajar

\section{PENDAHULUAN}

Pendidikan merupakan usaha yang dilakukan dalam rangka membantu seseorang mencapai kedewasaannya. Melalui pendidikan dapat tercemin kualitas suatu bangsa, oleh karena itu pemerintah berupaya memajukan pendidikan Indonesia dengan membuat Undang-Undang. Undang-undang nomor 20 Tahun 2003 tentang Sistem Pendidikan Nasional yang menyatakan bahwa pendidikan nasional berfungsi untuk pengembangan kemampuan serta pembentukan karakter dalam rangka mencerdaskan kehidupan bangsa dan membentuk peradaban yang bermartabat di tengah masyarakat dunia[1]. Implementasi dari Undang-Undang tersebut adalah perbaikan maupun pembaharuan kurikulum. Kurkulum yang berlaku di Indonesia saat ini adalah Kurikulum Tingkat Satuan Pendidikan dan Kurikulum 2013. Pembentukan Kurikulum 2013 merupakan bentuk penyempurnaan bagi Kurikulum sebelumnya yaitu KTSP.

Pelaksanaan Kurikulum 2013 mengarahkan pada pendekatan saintifik, dimana peserta didik dituntut untuk meningkatkan kemampuannya dalam 
melakukan observasi, bertanya, mengumpulkan data, mengasosiasi dan mengkomunikasikan. Penilaian dalam Kurikulum 2013 mengarah pada penilaian autentik dimana penilaian yang dilakukan secara komperehensif dan mempertimbangkan berbagai aspek mulai dari masukan, proses dan keluran. Menurut kurikulum 2013 model pembelajaran yang dapat diterapkan antara lain model pembelajaran berbasis masalah (Problem Solving), model pembelajaran berbasis proyek (Project Based Learning), model pembelajaran berbasis penemuan (Inquiry Learning dan Discovery Learning)[2].

Kenyataan di lapangan menunjukkan hasil yang berbeda, pembelajaran lebih sering dilakukan dengan metode yang berpusat pada guru (Teacher Centered Learning) karena dianggap lebih praktis dan efisien. Model pembelajaran ini didominasi oleh guru dan menuntut guru untuk langsung memberikan dan menginformasikan materi kepada siswa, sehingga siswa menjadi pasif untuk mengkonstruksi ideidenya. Model ini akan menimbulkan kejenuhan bagi siswa sehingga materi kurang diterima dengan baik dan tujuan pembelajaran tidak tercapai dengan optimal.

Pembelajaran kimia pada hakekatnya merupakan pembelajaran yang membutuhkan kemampuan pemecahan masalah. IImu kimia menggabungkan konsep, teori dan perhitungan matematis serta sebagian konsepnya yang bersifat abstrak sehingga menjadikan ilmu kimia sulit dipahami. Siswa yang mempelajari ilmu kimia harus mempelajari tiga hal, yaitu dunia nyata (makroskopis), dunia atom (mikroskopis), dan dunia lambang (simbolis). Menurut Pribula, konsep kimia yang abstrak sering kali hanya dapat dijelaskan tanpa ada visualisasi, sehingga siswa susah untauk memahami [3].

Hidrolisis garam adalah salah satu materi kimia yang dipelajari di kelas XI semester genap dalam Kurikulum 2013. Materi ini membutuhkan pemahaman dan penguasaan konsep dari materi sebelumnya yaitu reaksi asam-basa serta pemahaman senyawa asam dan basa. Sisa dituntut untuk dapat menganalisis garam-garam yang mengalami hidrolisis, merancang, melakukan, menyajikan dan menyimpulkan percobaan untuk menentukan jenis garam yang terhidrolisis serta menentukan $\mathrm{pH}$ garam yang terhidrolisis. Berdasarkan data Badan Standar Nasional Pendidikan mengenai Laporan Hasil Ujian Tahun pelajaran 2015/2016 menunjukkan nilai rata-rata Ujian Nasional di Surakarta untuk materi Hidrolisis garam sebesar 72,37, di provinsi Jawa Tengah sebesar 71,78 dan tingkat nasional 65,72. Data di atas menunjukkan materi Hidrolisis garam tergolong materi yang sulit bagi siswa.

Berdasarkan permasalahan di atas, perlu diupayakan suatu model pembelajaran yang sesuai dengan karakteristik siswa dan karakteristik materi hidrolisis garam. Model tersebut harus dapat mengaktifkan siswa dalam pembelajaran, sehingga dapat membantu siswa yang mengalami kesulitan belajar dan menghilangkan persepsi buruk siswa tentang kimia. Model pembelajaran yang sesuai dengan materi Hidrolisisgaram salah satunya adalah model Problem Solving.

Model pembelajaran Problem Solving merupakan salah satu model yang dianjurkan dalam Kurikulum 2013 dan dapat menjadi alternatif bagi guru untuk menjadikan pembelajaran di kelas efektif dan optimal. In Problem Solving models, students are responsible of their own learning and required not to depend too much on their teacher [4]. Pembelajaran problem solving menciptakan siswa yang mandiri dan dapat menyelesaikan masalah pembelajaran dengan cara mereka sendiri. Siswa dituntut untuk mampu menyelesaikan masalah melalui aktivitas dan penemuan berdasarkan teori, konsep, dan disiplin ilmu yang pernah mereka pelajari. Penelitian yang pernah dilakukan oleh fatoke et al menunjukkan bahwa model pembelajaran problem solving lebih efektif dibanding model pembelajaran konvensional [5].

Prosedur model pembelajaran Problem Solving adalah : (1) orientasi 
siswa terhadap masalah

mengorganisasi siswa untuk belajar (3) membimbing penyelidikan individu maupun kelompok (4) mengembangkan dan menyajikan penyelesaian masalah (5) analisis dan evaluasi proses penyelesaian [2]. Model pembelajaran problem solving terdapat 2 strategi yaitu algoritmik dan Heuristik [6]. Model pembelajaran problem solving secara algoritmik dilakukan secara terbimbing, dalam hal ini guru memberikan stimulus atau respon kepada siswa untuk membantu menyelesaikan masalah dan setelah siswa dirasa mahir stimulus tersebut dikurangi. Penyelesaian maalah dilakukan secara bertahap dan sistematis [7]. Model pembelajaran problem solving secara heuristik dilakukan secara mandiri, dimana siswa mencari dan mengumpulkan informasi penyelesaian masalah secara mandiri dan siswa bebas berkreasi menentukan jalan pintas penyeleasian masalah [8].

Berdasarkan uraian di atas model pembelajaran problem solving yang membutuhkan penyelesaian masalah perlu diimbangi dengan kemampuan berpikir kritis. Kemampuan berpikir kritis siswa akan digunakan manakala siswa menentukan solusi pemecahan masalah dalam pembelajaran kimia. Kemampuan berpikir kritis mencakup kemampuan analysis, interpretasi, evaluasi, mengumpulkan dan merefleksikan diri yang mendorong siswa untuk berpikir kreatif melalui logical resoaning analisis argument dan interpretasi logis [9]. Dalam materi hidrolisis garam, kemampuan berpikir kritis digunakan untuk memahami sifat larutan garam yang terhidrolisis, mengetahui jenis garam yang terhidrolisis sempurna maupun parsial, menentukan $\mathrm{pH}$ garam yang terhidrolisis. Penelitian ini membagi kemampuan berpikir kritis menjadi dua kategori yaitu tinggi dan rendah.

Dengan demikian, dilakukan penelitian tentang komparasi model pembelajaran problem solving secara algoritmik dan heuristik dengan kemampuan berpikir kritis terhadap prestasi belajar siswa pada materi pokok hidrolisis garam kelas XI MIPA SMA
Negeri 4 Surakarta Tahun pelajaran 2016/2017.

\section{METODE PENELITIAN}

Penelitian ini dilakukan di SMA Negeri 4 Surakarta pada kelas XI MIPA Semester Genap Tahun Pelajaran 2016/2017. Metode penelitian ini digunakan metode eksperimen dengan desain factorial $2 \times 2$. Desaian penelitian tersebut disajikan pada Tabel 1.

\begin{tabular}{|c|c|c|c|}
\hline \multirow{2}{*}{ Kelas } & \multirow{2}{*}{$\begin{array}{c}\text { Model } \\
\text { Pembelajaran }\end{array}$} & \multicolumn{2}{|c|}{$\begin{array}{l}\text { Kemampuan } \\
\text { Berpikir Kritis (B) }\end{array}$} \\
\hline & & $\begin{array}{l}\text { Tinggi } \\
\left(B_{1}\right)\end{array}$ & $\begin{array}{l}\text { Rendah } \\
\left(\mathrm{B}_{2}\right)\end{array}$ \\
\hline Eks I & $\begin{array}{l}\text { Problem } \\
\text { Solving } \\
\text { Secara } \\
\text { Algoritmik }\end{array}$ & $\mathrm{A}_{1} \mathrm{~B}_{1}$ & $\mathrm{~A}_{2} \mathrm{~B}_{1}$ \\
\hline Eks II & $\begin{array}{l}\text { Problem } \\
\text { Solving } \\
\text { Secara } \\
\text { Heuristik }\end{array}$ & $A_{1} B_{2}$ & $\mathrm{~A}_{2} \mathrm{~B}_{2}$ \\
\hline
\end{tabular}

Waktu penelitian dilaksanakan pada Desember 2016 sampai dengan Mei 2017 dengan subjek penelitian yaitu kelas XI MIPA 5 yang berjumlah 32 siswa dan kelas XI MIPA 7 yang berjumlah 32 siswa dengan pertimbangan bahwa kedua kelas memiliki kemampuan awal yang sama. Kelas XI MIPA 5 (Kelas Eksperimen I) diberikan perlakuan model pembelajaran problem solving secara algoritmik dan kelas XI MIPA 7 (Kelas Eksperimen II) diberi perlakuan model pembelajaran problem solving secara heuristik.

\section{HASIL DAN PEMBAHASAN}

Data dari penelitian ini adalah nilai kemampuan berpikir kritis siswa dan prestasi belajar pada materi hidrolisis garam yang meliputi aspek pengetahuan, sikap, dan ketrampilan. Berikut ini disajikan data hasil penelitian dari masing-masing variabel

\section{Data prestasi belajar aspek pengetahuan}

Kelas eksperimen I memiliki nilai tertinggi pada prestasi belajar aspek pengetahuan siswa sebesar 100, dan nilai terendahnya adalah 50 dengan nilai 
rata-rata sebesar 78,859. Kelas eksperimen II, nilai tertinggi prestasi belajar aspek pengetahuan adalah 100 dan nilai terendah adalah 60 dengan rata-rata sebesar 85,103 . Perbandingan distribusi frekuensi prestasi pengetahuan dapat dilihat pada Tabel 2 dan histogram perbandingan prestasi pengetahuan kelas eksperimen disajikan pada Gambar 1.

Tabel 2. Perbandingan Distribusi Frekuensi Prestasi Pengetahuan Siswa Kelas Eksperimen

\begin{tabular}{cccc}
\hline \multirow{2}{*}{ Interval } & \multirow{2}{*}{$\begin{array}{c}\text { Nilai } \\
\text { Tengah }\end{array}$} & \multicolumn{2}{c}{ Frekuensi } \\
\cline { 3 - 4 } & 53,5 & Eks I & Eks II \\
\hline $50-57$ & 53,5 & 0 \\
$58-65$ & 61,5 & 1 & 1 \\
$66-73$ & 69,5 & 6 & 4 \\
$74-81$ & 77,5 & 15 & 8 \\
$82-89$ & 85,5 & 4 & 6 \\
$90-97$ & 93,5 & 4 & 9 \\
$98-105$ & 101,5 & 1 & 4 \\
\hline \multicolumn{2}{c}{ Jumlah } & 32 & 32 \\
\hline
\end{tabular}

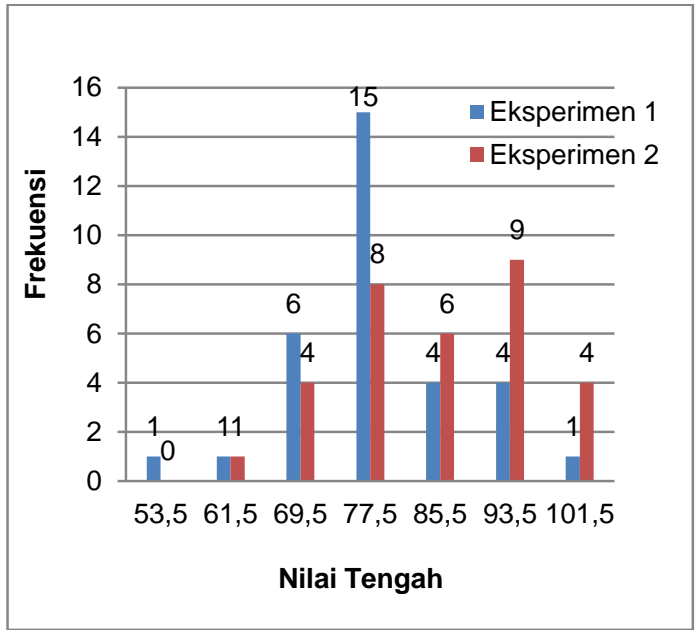

Gambar 1. Histogram Perbandingan Prestasi Pengetahuan Kelas Eksperimen

\section{Data prestasi belajar aspek sikap}

Kelas eksperimen I memiliki nilai tertinggi pada prestasi belajar aspek sikap adalah 4,00 dan terendah adalah 2,00 dengan nilai rata-rata sebesar 3,56 sedangkan pada kelas eksperimen II memiliki nilai belajar aspek sikap tertinggi adalah 4,00 dan terendah adalah 3,00 dengan nilai rata-rata sebesar 3,56. Perbandingan distribusi frekuensi prestasi aspek sikap dapat dilihat pada Tabel 3 dan histogram perbandingan prestasi sikap kelas eksperimen disajikan pada Gambar 2.

Tabel 3. Perbandingan Distribusi Frekuensi Prestasi Sikap Siswa Kelas Eksperimen

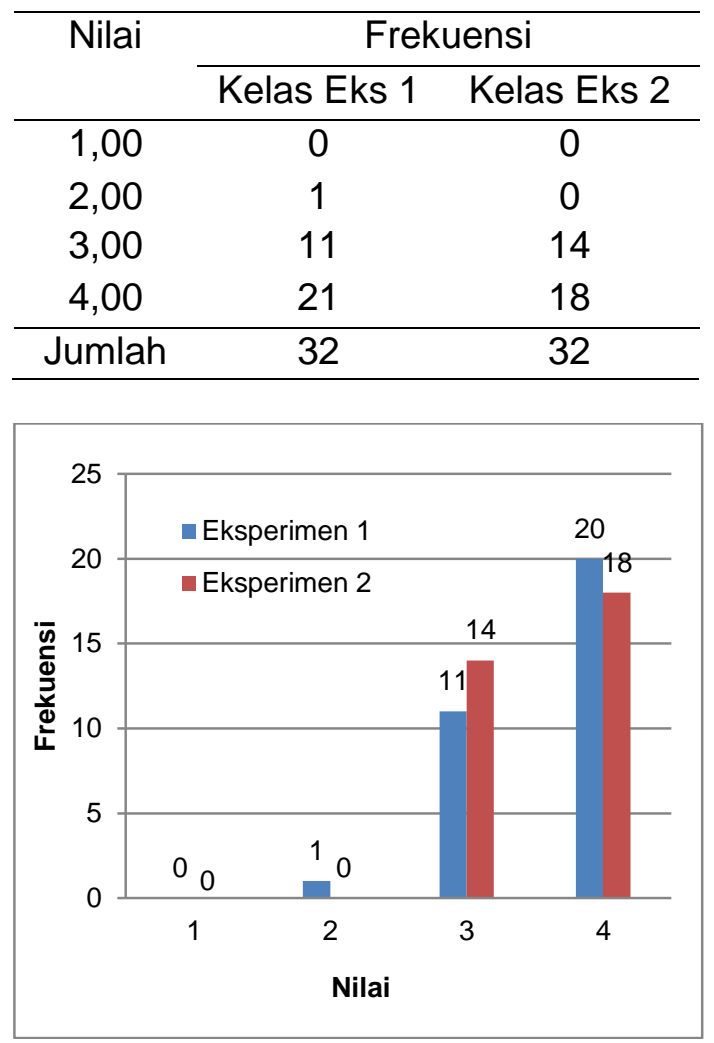

Gambar 2. Histogram Perbandingan Prestasi Sikap kelas Eksperimen

\section{Data prestasi belajar aspek ketrampilan}

Kelas eksperimen I nilai tertinggi pada aspek ketrampilan adalah 100 dan nilai terendah adalah 90 dengan rata-rata nilai sebesar 93,68. Kelas eksperimen II memiliki nilai tertinggi prestasi pada aspek ketrampilan sebesar 100 dan nilai terendah sebesar 85 dengan nilai ratarata sebesar 94,53. Perbandingan distribusi frekuensi prestasi aspek ketrampilan dapat dilihat pada Tabel 4 dan histogram perbandingan prestasi ketrampilan kelas eksperimen disajikan pada Gambar 3. 
Tabel 4. Perbandingan Distribusi Frekuensi Prestasi ketrampilan Siswa Kelas Eksperimen

\begin{tabular}{cccc}
\hline Interval & Nilai & \multicolumn{2}{c}{ Frekuensi } \\
\cline { 3 - 4 } & Tengah & Eks I & Eks II \\
\hline $85-87,1$ & 86,05 & 0 & 1 \\
$87,2-89,3$ & 88,25 & 0 & 0 \\
$89,4-91,5$ & 90,45 & 8 & 4 \\
$91,6-93,7$ & 92,65 & 11 & 4 \\
$93,8-95,9$ & 94,85 & 0 & 7 \\
$96-98,1$ & 97,05 & 10 & 14 \\
$98,2-100,3$ & 99,25 & 3 & 2 \\
\hline Jumlah & & 32 & 32 \\
\hline
\end{tabular}

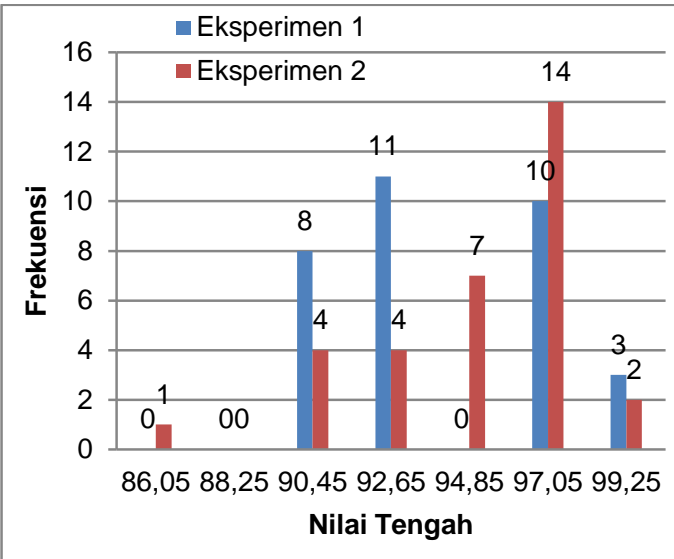

Gambar 3. Histogram Perbandingan Prestasi Ketrampilan Kelas Eksperimen

\section{Pengujian Hipotesis}

Pengujian hipotesis dilakukan dengan analisis variansi (ANAVA) dua jalan dengan sel tak sama. Sebelum dilakukan uji ANAVA, terdapat beberapa persyaratan analisis yang harus dipenuhi yaitu uji normalitas dan uji homogenitas variansi. Uji normalitas dan uji homogenitas dilakukan dengan bantuan software IBM SPSS v. 21. Tujuan dari uji normalitas adalah untuk mengetahui data penelitian berasal dari distribusi normal atau tidak, sedangkan uji homogenitas variansi bertujuan untuk mengetahui apakah data penelitian memiliki variansi yang sama atau tidak. Data yang tidak mememenuhi persyaratan analisis, pengujian hipotesis dilakukan dengan uji statistik non parametric Kruskal Wallis. Hasil dari uji normalitas dan uji homogenitas disajikan pada Tabel 5 dan Tabel 6.

Berdasarkan Tabel 5 dan 6 , data penelitian yang memenuhi prasyarat analisis anava adalah data prestasi belajar aspek pengetahuan saja, sedangkan data prestasi belajar aspek sikap dan ketrampilan tidak memenuhi syarat analisis, sehingga pengujian hipotesis digunakan analisis non parametik Kruskal Wallis.

Tabel 5. Hasil Uji Normalitas

\begin{tabular}{cccccccc}
\hline $\begin{array}{c}\text { Kelompok } \\
\text { Siswa }\end{array}$ & $\alpha$ & \multicolumn{2}{c}{ Pengetahuan } & \multicolumn{2}{c}{ Sikap } & \multicolumn{2}{c}{ Ketrampilan } \\
\cline { 3 - 7 } & & Sig & Kesimpulan & Sig & Kesimpulan & Sig & Kesimpulan \\
\hline $\mathrm{A}_{1}$ & 0,05 & 0.167 & Normal & 0.000 & Tidak Normal & 0.002 & Tidak Normal \\
$\mathrm{A}_{2}$ & 0,05 & 0.107 & Normal & 0.000 & Tidak Normal & 0.000 & Tidak Normal \\
$\mathrm{B}_{1}$ & 0,05 & 0.06 & Normal & 0.000 & Tidak Normal & 0.036 & Tidak Normal \\
$\mathrm{B}_{2}$ & 0,05 & 0.174 & Normal & 0.000 & Tidak Normal & 0.000 & Tidak Normal \\
$\mathrm{A}_{1} \mathrm{~B} 1$ & 0,05 & 0.287 & Normal & 0.000 & Tidak Normal & 0.001 & Tidak Normal \\
$\mathrm{A}_{1} \mathrm{~B}_{2}$ & 0,05 & 0.265 & Normal & 0.002 & Tidak Normal & 0.000 & Tidak Normal \\
$\mathrm{A}_{2} \mathrm{~B}_{1}$ & 0,05 & 0.071 & Normal & 0.000 & Tidak Normal & 0.001 & Tidak Normal \\
$\mathrm{A}_{2} \mathrm{~B}_{2}$ & 0,05 & 0.0179 & Normal & 0.000 & Tidak Normal & 0.006 & Tidak Normal \\
\hline
\end{tabular}

Tabel 6 Hasil Uji Homogenitas

\begin{tabular}{|c|c|c|c|c|c|c|c|}
\hline \multirow{2}{*}{ Uji Homogenitas } & \multirow[b]{2}{*}{$\alpha$} & \multicolumn{2}{|c|}{ Pengetahuan } & \multicolumn{2}{|r|}{ Sikap } & \multicolumn{2}{|c|}{ Ketrampilan } \\
\hline & & Sig & Kesimpulan & Sig & Kesimpulan & Sig & Kesimpulan \\
\hline $\begin{array}{l}\text { Ditinjau dari Model } \\
\text { Pembelajaran }\end{array}$ & 0,05 & 0,683 & Homogen & 0,683 & Homogen & 0,320 & Homogen \\
\hline $\begin{array}{l}\text { Ditinjau dari kemampuan } \\
\text { berpikir kritis }\end{array}$ & 0,05 & 0,198 & Homogen & 0,164 & Homogen & 0,159 & Homogen \\
\hline Ditinjau dari antar sel & 0,05 & 0,335 & Homogen & 0,031 & $\begin{array}{c}\text { Tidak } \\
\text { homogen }\end{array}$ & 0,651 & Homogen \\
\hline
\end{tabular}




\section{a. Hipotesis pertama}

Hasil ANAVA dua jalan dengan sel tak sama pada hipotesis pertama diperoleh hasil nilai Signifikansi (Sig) $(0,010)<(0,05)$ yang berarti bahwa $H_{0}$ ditolak. Berdasarkan data tersebut, dapat disimpulkan bahwa terdapat pengaruh antara model pembelajaran problem solving secara algoritmik dan heuristic terhadap prestasi belajar siswa aspek pengetahuan pada materi hidolisis garam. Hal tersebut dapat dilihat pula dari hasil rata-rata nilai prestasi belajar aspek pengetahuan materi hidrolisis garam. Kelas eksperimen I (model problem solving secara algoritmik) memperoleh rata-rata nilai sebesar 78,859; sedangkan kelas eksperimen II (model problem solving secara heuristik) memperoleh nilai sebesar 85,103.

Pada kelas yang diterapkan model problem solving secara algoritmik dilakukan dengan pembelajaran problem solving dimana siswa diarahkan untuk berpikir secara deduktif melalui pendekatan terbimbing. Pendekatan terbimbing dilakukan dengan memberikan petunjuk atau stimulus kepada siswa untuk menyelesaikan permasalahan dalam pembelajaran, kemudian setelah siswa dirasa cukup ahli stimulus tersebut dikurangi atau dihilangkan. Pembelajaran dengan model Problem Solving strategi Algoritmik ini membuat siswa dapat menciptakan solusi yang akurat dan sesuai dengan permasalahan. $\mathrm{Pe}$ laksanaan pembelajaran dengan model ini terdapat siswa yang antusias dan termotivasi untuk menyelesaikan persoalan dalam pembelajaran setelah mendapat bimbingan dari guru, namun terdapat pula siswa yang pasif dan hanya menunggu teman atau guru dalam menyelesaikan permasalahan tersebut. $\mathrm{Hal}$ ini seacara tidak langsung menyebabkan siswa menjadi ketergantungan terhadap teman atau guru, sehingga kurang menguasai materi pelajaran.

Model pembelajaran Problem Solving secara Heuristik, siswa dilatih untuk berkreasi menyelesaikan permasalahan menggunakan kemampuan berpikir kritisnya dalam menemukan solusi yang tepat. Cara yang digunakan siswa dalam menyelesaikan permasalaahan adalah dengan mencari pada sumber materi atau dengan berdiskusi dengan teman sekelompoknya. Kelebihan lain dalam model pembelajaran ini adalah siswa dilatih untuk berpikir kritis menemukan solusi permasalahan dalam materi hidrolisis garam, sehingga siswa akan lebih tangkas dan terlatih ketika menjumpai persoalan yang serupa. Pembelajaran ini menuntut siswa bekerja secara mandiri dalam mengumpulkan informasi untuk penyelesaian masalah dan guru hanya memberikan sedikit bimbingan. Hal tersebut lebih efektif pada siswa karena siswa mau berusaha dan tidak pasif selama pembelajaran.

Hasil uji statistik Kruskal Wallis untuk pengaruh model pembelajaran terhadap aspek sikap menunjukkan nilai Asymp.Sig $(0,695)>(0,05)$ maka $\mathrm{H}_{0}$ diterima yang berarti bahwa penerapan model problem solving secara algoritmik dan heuristik tidak memberikan pengaruh terhadap aspek sikap. Ratarata aspek sikap kedua kelas yang tiak berbeda jauh mendukung hasil uji Kruskal Wallis. Kelas eksperimen I memiliki rata-rata 3,59 dan kelas eksperimen II memiliki rata-rata 3,56.

Prestasi belajas aspek sikap lebih dipengaruhi oleh faktor internal dari dalam diri siswa, sedangkan faktor eksternal kurang berpengaruh. Model pembelajaran dalam hal ini adalah faktor eksternal. Hal tersebut sesuai dengan penelitian sebelumnya yaitu penelitian dari Rybsczynski dan Schussler (2013) yang mengatakan bahwa model pembelajaran bukanlah faktor penting yang mempengaruhi sikap siswa, karakteristik personal siswa lah yang mempengaruhi sikap siswa [10].

Hasil yang sama ditunjukkan oleh pengaruh model pembelajaran terhadap aspek ketrampilan dimana uji Kruskal Wallis menunjukkan nilai Asymp.Sig $(0,199)>(0,05)$ maka $\mathrm{H}_{0}$ diterima, artinya tidak terdapat pengaruh model pembelajaran terhadap aspek ketrampilan. Hasil tersebut juga didukung dengan nilai rata-rata aspek ketrampilan kedua kela yang hampir sama yaitu 94,428 untuk kelas 
eksperimen I dan 95,5 untuk kelas eksperimen II. Hal ini dikarenakan baik siswa yang diberikan model pembelajaran problem solving secara algoritmik maupun secara heuristik sama-sama terlibat aktif dalam praktikum, menyusun laporan dengan baik, dan mengerjakan tugas produk dengan baik sehingga keduanya sama sama mencapai nilai prestasi yang baik.

\section{b. Hipotesis Kedua}

Hasil uji ANAVA dua jalan dengan sel tak sama untuk pengaruh kemampuan berpikir kritis terhadap prestasi belajar aspek pengetahuan menunjukkan nilai signifikansi sebesar $(0,026)<(0,05)$ yang berarti $\mathrm{H}_{0}$ ditolak. Hal ini berarti ada pengaruh yang signifikan antara siswa dengan kemampuan berpikir kritis tinggi dan rendah dengan prestasi belajar siswa aspek pengetahuan pada materi hidrolisis garam.

Materi Hidrolisis Garam merupakan materi kimia yang memiliki karakteristik membutuhkan pemahaman konsep yang kuat terkait materi sebelumnya yaitu larutan asam-basa, dan juga terdapat perhitungan matematis. Materi ini berkaitan dengan kemampuan berpikir kritis, dimana kemampuan berpikir kritis akan membantu siswa untuk memahami sifat larutan hidrolisis dan mengetahui jenis garam yang terhidrolisis sempurna dan terhidrolisis parsial, kelenturan atau fleksibilitas dan orisinalitas siswa diharapkan mampu memunculkan ideide tentang cara menemukan solusi dalam permasalahan yang diberikan.

Jika kemampuan berpikir kritis siswa tinggi, maka akan lebih mudah untuk menemukan solusi untuk memecahkan masalah dalam pembelajaran, sebaliknya jika kemampuan berpikir kritis siswa rendah akan mengalami kesulitan dalam memecahkan persoalan yang berkaitan dengan hidrolisis garam. Dalam hal ini, kemampuan bepikir kritis digunakan untuk menghasilkan produk baru atau kombinasi dari hal-hal yang sudah ada sebelumnya seperti fakta atau informasi untuk dirangkai menjadi solusi yang tepat. Dalam penelitian ini diperoleh bahwa siswa dengan kemampuan berpikir kritis tinggi memiliki nilai prestasi belajar aspek pengetahuan lebih baik dari siswa dengan kemampuan berpikir kritis rendah. Hal tersebut sesuai dengan penelitian yang dilakukan oleh Lukitasari (2013) kemampuan berpikir kritis dibutuhkan untuk dapat menentukan solusi apa saja yang mungkin dapat menyelesaikan permasalahan dan apa alasannya [11].

Hasil uji non parametik Kruskal Wallis untuk pengaruh kemampuan berpikir kritis siswa terhadap prestasi belajar aspek sikap menunjukkan Asymp.Sig $(0,695)>(0,05)$ yang berarti bahwa $\mathrm{H}_{0}$ diterima, artinya tidak ada pengaruh kemampuan berpikir kritis siswa terhadap prestasi belajar aspek sikap. Aspek sikap meliputi sikap spiritual dan sikap sosial yang meliputi jujur, tanggungjawab, disiplin, kerjasama, dan percaya diri. Sedangkan Kemampuan berpikir kritis meliputi kemampuan analysis, interpretasi, evaluasi, mengumpulkan dan merefleksikan diri [10]. Aspek sikap lebih dominan dipengaruhi faktor internal dan kemampuan berpikir kritis sebagai faktor eksternal kurang mempengaruhi.

Kemampuan berpikir kritis memberikan pengaruh terhadap aspek ketrampilan. Hal tersebut terbukti dengan hasil uji non parametik Kruskal Wallis dengan nilai Asymp.Sig $(0,021)<(0,05)$ yang berarti terdapat pengaruh yang signifikan antara kemampuan berpikir kritis dengan aspek ketrampilan. Nilai rata-rata aspek ketrampilan siswa dengan kemampuan berpikir kritis tinggi adalah 93,96 dan siswa dengan kemampuan berpikir kritis rendah adalah 94,96. Hasil tersebut mengatakan bahwa siswa yang masuk ke dalam kelompok kemampuan berpikir kritis tinggi belum tentu memiliki prestasi belajar aspek ketrampilan yang lebih baik daripada siswa yang masuk dalam kelompok kemampuan berpikir kritis rendah.

\section{c. Hipotesis ketiga}

Hasil uji ANAVA dua jalan dengan sel tak sama untuk pengaruh interaksi antara prestasi belajar aspek pengetahuan menunjukkan nilai 
signifikansi $(0,658)>(0,05)$ yang berarti $\mathrm{H}_{\mathrm{OAB}}$ diterima. Uji non parametik Kruskall Wallis untuk aspek sikap menunjukkan nilai Asymp.Sig sebesar $(0,078)>(0,05)$ berarti $\mathrm{H}_{\mathrm{OAB}}$ diterima, sedangkan untuk aspek ketrampilan menunjukkan hasil Asymp.Sig sebesar $(0,071)>(0,05)$ yang juga berarti $\mathrm{H}_{O A B}$ diterima. Ketiga hasil tersebut mengatakan bahwa tidak ada interaksi antara model pembelajaran problem solving secara algoritmik dan heuristik dengan kemampuan berpikir kritis terhadap prestasi belajar asepk pengetahuan, sikap, dan ketrampilan.

Hasil di atas menunjukkan bahwa siswa dengan kemampuan berpikir kritis tinggi yang dikenai model pembelajaran problem solving secara algoritmik maupun heuristik memiliki prestasi belajar yang tinggi dan sebaliknya.

\section{KESIMPULAN}

Berdasarkan hasil penelitian dapat disimpulkan (1) Terdapat pengaruh model pembelajaran Problem Solving Strategi Algoritmik dan Problem Solving Strategi Heuristik terhadap prestasi belajar aspek pengetahuan, tetapi tidak berpengaruh terhadap aspek sikap dan ketrampilan (2) Terdapat pengaruh kemampuan berpikir kritis tinggi dan rendah terhadap prestasi belajar aspek pengetahuan dan ketrampilan, tetapi tidak berpengaruh pada aspek sikap. (3) Tidak ada interaksi antara model pembelajaran Problem Solving secara Algoritmik dan Problem Solving secara Heuristik dengan kemampuan berpikir kritis terhadap prestasi belajar aspek sikap, pengetahuan, maupun ketrampilan.

\section{DAFTAR RUJUKAN}

[1] Departemen Pendidikan Nasional. (2003). Undang-Undang Nomor 20 Tahun 2003 tentang Sistem Pendidikan Nasional. Jakarta: Sekertariat Jendral.

[2] Kementrian Pendidikan dan Kebudayaan. (2014a). Peraturan Menteri Pendidikan dan Kebudayaan Nomor 59 Tahun 2014 tentang Kurikulum 2013
Sekolah Menengah Atas/ Madrasah Aliyah.

[3] Ashadi. (2009). Kesulitan Belajar Bagi Siswa Sekolah Menegah. UPT Perpustakaa UNS. Diperoleh 12 Januari 2017, dari http://pustaka.uns.ac.id.

[4] Syafi'I.W \& Yasin R.M. (2013). Problem Solving Skills and Learning Achievments through Problem-Based Module in teaching and learning Biology in High Scholl. Journal of Asian Social Science, 9(10) 220-228.

[5] Handini, O., 2014, Pengaruh Model Pembelajaran Algoritmik-Heuristik dan Gaya Belajar terhadap Hasil Belajar Mata Kuliah Perkembangan Peserta Didik Pada Mahasiswa Program Studi Sekolah Dasar Fakultas Keguruan dan IImu Pendidikan Universitas Slamet Riyadi Surakarta Tahun 2013, Jurnal Profesi Pendidik, 1(6), 5763.

[6] Landa, L.N. (1984). Algo-Heuristik Theory of Perfomances, Learning, and Instructions: Subject, Problem, Principles. Contempory Educational Psychologi, 9, 235245.

[7] Klein, S. B. (1996). Learning Principle and Applications. Third Edition. New York : Mc Graw Hill

[8] Armstrong, M. (1994). Manajemen Sumber Daya Manusia. A Handbook of Human Resouscr Management: PT. Elex Media Komputindo.

[9] Zhou,Q., Huang,Q., \& Tian,H. (2013). Developing Students' Critical Thingking Skills by TaskBased Learning in Chemistry Experiment Teaching. Journal of Scientific Research, 4(12), 40-45 
[10] Rybsczynski, S.H., Schussler,E. (2013). Effect of Instructional Model on Student Attitude in an Introductory Biology Laboratory. International Journal for the Scholarship Teaching and Learning. 7(2), article 22.
[11] Lukitasari, D.R. (2013). Upaya Meningkatkan Kemampuan Berpikir Kritis Siswa Melalui Model Pembelajaran Berbasis Masalah Dengan Berbantuan Film Sebagai Sumber Belajar Pada Pokok Bahasan Sikap Pantang Menyerah Dan Ulet Kelas X Pm Smk N 1 Batang. Skripsi. Universitas Negeri Semarang, Semarang . 